\title{
- ГАСТРОНОМІЧНИЙ ТУРИЗМ ЯК АКТУАЛЬНИЙ ТРЕНД СУЧАСНОї КУЛЬТУРИ
}

\section{- Красовський Сергій Олександрович}

Кандидат культурології, ORCID: 0000-0001-9314-7594, e-mail: krasovskiis89@gmail.com, Київський національний університет культури і мистецтв, вул. Є. Коновальця, 36, Київ, Україна, 01133

\section{- Для цитування:}

Красовський, С.О. (2021). Гастрономічний туризм як актуальний тренд сучасної культури. Питання культурологіï, (37), 169-180. doi: https://doi.org/10.31866/2410-1311.37.2021.236018.

\section{Анотація}

Мета статті - проаналізувати формування та розвиток гастрономічного туризму в контексті соціокультурного вектора розуміння сутності туристичної діяльності. Методологія дослідження ґрунтується на застосуванні системно-структурного підходу, орієнтованого на вивчення туризму як цілісного соціокультурного явища. Наукова новизна полягає в тому, що вперше сутність гастрономічного туризму розглянуто в соціокультурному аспекті, що дає підстави визначити його як значущий реагент впливу на соціальні процеси. Висновки. Гастрономічний туризм доволі молодий напрям, який активно розвивається, але вже сьогодні туристи віддають перевагу пізнанню традицій і звичаїв іншої країни шляхом дегустації національних страв і напоїв. Відтак, враховуючи, що гастрономічна традиція - це процес, що постійно розвивається, завдання для професіоналів полягає в залученні інновацій, оновленні й адаптації своїх пропозицій до потреб нової споживчої культури. Тенденції розвитку гастрономічного туризму у світі дають підстави вважати його стійким трендом, який уможливлює взаємодію мандрівників із місцевими громадами. В умовах зростання конкуренції за увагу користувача і появи нових технологій бізнес-суб'єктам необхідно оперативно формувати оновлені стратегії просування. Визначено, що Україна має потенціал для підвищення міжнародної конкурентоспроможності туристичної галузі, зокрема завдяки посиленню мультикультуралізму туристичних потоків, зростанню попиту на нові туристичні дестинації, різноманітності культурного і природного ландшафту. Звернено увагу на потребу з'ясування чітких векторів розвитку гастрономічного туризму в країні, розробки відповідної державної підтримки туристичних дестинацій, туристичних фрірм та інших стейкхолдерів, а також дослідження соціокультурних якостей туризму в контексті соціальних міграцій і діалектичної взаємодії загальносвітових процесів глобалізації та регіоналізації.

Ключові слова: туризм; гастрономічний туризм; дестинація; національна культура; ринок туристичних послуг 


\section{- Вступ}

Розвиток туристичної галузі $€$ одним із визначальних складників доходу в багатьох розвинених країнах світу і країнах, що розвиваються; однією із найперспективніших галузей сфрери послуг. Крім економічної фрункції, туризм сприяє налагодженню зв'язків між різними націями, розширенню світогляду людини, відновленню її психофрізичного стану, а також фрормуванню дбайливого ставлення до природно-культурного надбання країни. Кожен кулінарний досвід аромат і смак страви тощо - це спогад про конкретну територію, відтак їжа і дестинації тісно пов'язані між собою: вони формують основу, включену в розвиток економіки вражень, основу, яка дає можливість по-новому розвивати дестинації. Йдеться про індустрію туризму вражень - більш «зануреної», автентичної, активної і наповненої пригодами подорожі. Не випадково понад третина туристичних витрат виділяється на харчування, а у 22 \% європейців головна мотивація подорожі - культурний досвід, який охоплює кулінарне мистецтво (Егорова \& Лях, 2016). Водночас якщо середній чек звичайного туриста дорівнює $€ 50$, то середній чек туриста гастрономічного маршруту — Є200 (Горова, 2020), а обсяг світового ринку гастрономічного туризму оцінюється в 42 млрд доларів США (Ковешніков \& Гармаш, 2017).

В останні роки сформувалися нові тренди споживчих переваг у туризмі, пов'язані з персоніфікацією турпродукту і прагненням сучасного мандрівника отримати унікальний досвід, пізнати життя місцевої громади, ії̈ звичаї, традиції, зокрема й кулінарні. Таким тенденціям розвитку попиту на вид подорожей, в яких турист набуває унікальний досвід, пізнаючи країни, регіони і народи через їх кухню, відповідає гастрономічний туризм. Попри те, що цей вид туризму відкриває величезні можливості для просування місцевої культури, задоволення різноманітних вимог мандрівників, поняття гастрономічного туризму залишається недостатньо відомим широкій аудиторії, і мандрівники, вирушаючи на кулінарний майстер-клас, не знають, що беруть участь в активності, яка належить до цього типу туризму. На додаток серед вчених немає єдиного розуміння його сутності як синтезу екології, гастрономії і виробництва, що активно залучає туристів з різних куточків світу, допомагає дізнатися традиції різних регіонів планети, ознайомитися з місцевим населенням і в разі потреби зруйнувати стереотипи про країну.

Уперше термін «кулінарний туризм» був уведений в обіг у 1998 р. викладачем Державного університету Боулінг Грін (США) Люсі Лонг для вираження ідеї про те, що люди пізнають інші культури завдяки місцевій їжі. Сьогодні в спеціальній літературі зустрічаються такі поняття: «culinary tourism» - «кулінарний туризм», «food tourism» - «продовольчий туризм», «gastronomic tourism» «гастрономічний туризм». Відсутність уніфікованої назви цього виду туризму в англійській мові створює певні труднощі для дослідження явища в багатьох інших країнах. Так, до 2012 року поширеним був термін «кулінарний туризм», згодом замінений на «гастрономічний туризм» через те, що, згідно із дослідженням Міжнародної асоціації гастрономічного туризму, більшість американських жителів вважали, що кулінарний туризм підходить тільки для еліти (Leser, 1997). У сучасному світі гастрономічний туризм - це вид туризму, коли туристи та відвідувачі, які планують частково або повністю спробувати кухню певної місцево- 
сті або здійснити заходи, пов'язані з гастрономією, відвідують певні дестинації (Линькова \& Максименко, 2016, с. 188).

Питання розвитку гастрономічного туризму знаходять широке відображення в спеціальній літературі. Зокрема, в Україні це роботи таких дослідників, як В. Гармаш і В. Ковешніков (2017), В. Глушко (2016), О. Коркуна, О. Никига і О. Підвальна (2020), В. Корнілова і Н. Корнілова (2018), Т. Кукліна (2013), I. Нестерчук (2017), Г. Саркісян (2020) та багато інших, у працях яких зроблено спроби систематизувати не лише підходи до визначення поняття гастрономічного туризму, його різновидів та особливостей, а й звернено увагу на його історію, сучасні практики і тенденції розвитку, роль і значення стимулювання гастрономічного туризму в Україні тощо. Попри результати, отримані цими та іншими вченими у процесі своїх досліджень, у сучасній культурології науковий і практичний інтерес до розвитку гастрономічного туризму все ще формується, у профільних публікаціях ця проблематика представлена недостатньо і вимагає звернення уваги на уточнення сутності гастрономічного туризму як соціокультурного явища.

\section{- Мета статті}

Мета статті - проаналізувати формування та розвиток гастрономічного туризму в контексті соціокультурного вектора розуміння сутності туристичної діяльності. Методологія дослідження ґрунтується на застосуванні системно-структурного підходу, орієнтованого на вивчення туризму як цілісного соціокультурного явища. Наукова новизна полягає в тому, що вперше сутність гастрономічного туризму розглянуто в соціокультурному аспекті, що дає підстави визначити його як значущий реагент впливу на соціальні процеси.

\section{- Виклад матеріалу дослідження}

Кулінарні традиції народів формувалися століттями, відчуваючи на собі дію таких чинників, як вплив клімату і географрічного положення, економічного добробуту країни і силу впливу інших культур. 3 плином часу складався етнос країн, який і став основою у формуванні гастрономічних відмінностей. Відвідуючи будь-яку країну світу, туристи насамперед ознайомлюються з її культурою і традиціями. Їжа та ритуали її прийняття завжди були найбільш важливими і значущими елементами культури для всіх націй. Люди, бувши всеїдними представниками своєї культури, харчуються по-різному, віддаючи переваги різному набору продуктів, який вони вживають, а також самому процесу прийняття їжі. Не випадково побутує вислів: «Хочеш пізнати культуру будь-якої країни — спробуй ії на смак», - саме це і є основою формування гастрономічного напряму в туризмі.

Серед основних світових тенденцій, які можна спостерігати в розвитку гастрономічного туризму: зростання ринку і збільшення гастрономічного туризму в усьому світі; це один із найдинамічніших сегментів туристичного ринку; продукт $є$ основою для гастрономічного туризму; зацікавленість культурною спадщиною. У цьому контексті культура - це набір моделей поведінки, знань і навичок, які фрормують суспільство, засноване на почутті приналежності. Фор- 
ма будь-якої гастрономічної туристичної пропозиції не буде життєздатною, якщо вона не враховує культурні особливості території. Гастрономічний туризм є безумовним складником будь-якого іншого виду туризму, зокрема сільського, ділового, подієвого, освітнього, спортивного та культурно-пізнавального. Так, сільський, або зелений, гастрономічний туризм безпосередньо суміщений з агротуризмом. Мета таких турів полягає в проживанні за містом, поруч з природою, пізнаючи сільське життя. Заняттям туристів у зазначених турах є звичайне життя селян: постійний контакт із природою і тваринами, робота по господарству, збір врожаю, приготування традиційних домашніх страв із самостійно вирощених натуральних продуктів.

Гастрономічний туризм - один із найпопулярніших видів туризму, тісно «вплетених» у бізнес-тури. Під час ділових поїздок туристи відвідують не лише різноманітні підприємства, а й відомі кафе, бари і ресторани, щоб встигнути дізнатися гастрономічні традиції нового місця. Своєю чергою метою подієвих або фестивальних турів $\epsilon$ відвідання певної події, пов'язаної із приготуванням чи вживанням їжі, зокрема гастрономічного фестивалю, на якому учасники ознайомлюються з новими містами шляхом занурення в особливості місцевої кухні. Освітній гастрономічний тур - це більше подія з професійною орієнтацією, ніж подорож, оскільки його мета - навчання в кулінарних освітніх закладах або проходження різних кулінарних курсів і майстер-класів для набуття відповідних навичок. Різновид спортивного туризму - полювання і рибальство безпосередньо пов'язані зі споживанням уловів і видобутку. І, нарешті, суть культурно-пізнавального туру досить неоднозначна, тому що це скоріше комбінований тур, мета якого розширюється до двох складових: ознайомлення з визначними пам'ятками країни й одночасно її кухнею, при цьому жодна з них не відсувається на другий план проти іншої. Говорячи про культуру і звичаї населення певного регіону, ознайомлення з ними у разі з гастрономічним туризмом відбувається через національну кухню, національні костюми, традиційну подачу страв. У разі з історичним туризмом ознайомлення з культурою та звичаями відбуваються через історію і відвідування історичних місць з супроводом гідів-істориків. Виходячи з викладеного, об'єктами гастрономічного туризму є: країна, що має кулінарну привабливість; регіони, які популярні продуктами, виробленими на цій території; ресторани, які пропонують ексклюзивне меню і високо оцінюються провідними критиками світу у сфері кулінарії; підприємства, відомі своєю виробленою кулінарною продукцією, наприклад, шоколадні фрабрики; установи, які пропонують програми навчання для набуття кулінарних навичок, і які випускають найкращих кухарів світу; різні конференції, присвячені гастрономічному туризму, фестивалі, ярмарки та ін. Отже, компонентами гастрономічного бренду $є$ добре розвинена сфера туризму і гастрономії; наявність традиційних ресторанів і кваліфрікованих кухарів; гастрономічні фрестивалі, заходи, конкурси; просування гастрономії в освітні заклади.

Основна мета гастрономічних турів, безперечно, полягає в тому, щоб отримати задоволення від споживання страв кухні тієї чи іншої країни. Однак ця мета не зводиться до того, щоб спробувати якусь рідкісну, екзотичну страву або скуштувати незліченну кількість страв. Насправді основне завдання полягає 
в тому, щоб спробувати страви, які поєднують у собі рецепти, відповідні традиціям, звичаям місцевих жителів, їх культурі приготування їжі, а також технологіям її приготування. Під час подорожі турист куштує різні кулінарні шедеври, напої країни тимчасового перебування, відвідує місця вирощування і виробництва окремих продуктів. Ця особливість гастрономічного туризму підтверджується світовим трендом на важливість досвіду і вражень, а не матеріальних благ у туризмі: 67 \% забезпечених туристів воліють витрачати кошти на враження, а не на дорогий готель (Skift Megatrends, n.d.). Крім того, часто туристи обирають тур тільки тому, що в іншому місці подібний досвід буде недоступний (Chan et al., 2016, p. 27). Паралельно із зростанням цього тренду збільшується кількість туристів, які хочуть побачити життя місцевої громади та подорожувати «Like a local». Вони заперечують негативний образ типового туриста, прагнуть пізнати культуру та історію країни. Так, 57 \% туристів хочуть під час своєї поїздки спілкуватися з місцевими жителями, а 43 \% вважають похід на вечерю в заклад «для місцевих» досвідом, що запам'ятовується (American Express, 2018). Симбіоз цих трендів призводить до все більшої популярності гастрономічного туризму як способу ближче ознайомитися з культурою дестинації, зокрема завдяки збільшенню впливу соціальних мереж на користувачів (Travel and Tourism Research Association, 2019). Особливу значущість у зв'язку із цим має соціальна мережа Instagram, яка дає можливість туристам ділитися своїм гастрономічним досвідом у вигляді фотографій і відео з друзями та підписниками. У соціальних мережах з'являються спеціальні хештеги, які транслюють отримання задоволення від їжі (Ranteallo \& Andilolo, 2017, p. 120). Більш ніж половина експертів впевнені, що на розвиток гастрономічного туризму найперше впливають саме соціальні медіа (World Food Travel Association, n.d.), що вимагає від турфірм ефективно використовувати цей канал для просування своїх послуг.

Нині гастрономічний туризм стає модним напрямом і набирає все більшого попиту серед туристів. Уже зараз $є$ велика кількість охочих відвідати іншу країну, щоб дізнатися кулінарні звички і традиції того чи іншого народу. Цей вид туризму $€$ досить молодим: попри те, що він існує протягом століть, визнавати його як самостійний вид і вивчати почали лише в кінці минулого століття. Внаслідок цього на туристичному ринку з кожним роком з'являються нові фрорми гастрономічних туристичних послуг. Гастрономічний тур як послуга - це щось більше, ніж просто подорож, оскільки він $є$ добре продуманим комплексом заходів для дегустації традиційних у певній місцевості страв або окремих продуктів. Серед тенденцій, які сприяють розвитку гастрономічного туризму, можна виокремити такі:

- зростання добробуту населення істотно впливає на споживчі витрати. Споживачі витрачають більшу частину свого доходу на готову їжу, продукти для гурманів, їжу поза домом і харчування з тією або іншою формою користі для здоров'я;

- демографія і домашні зміни. Старіння населення і зміна способу життя призвели до збільшення попиту на їжу поза домом і можливості для гастрономічного туризму;

- відмова від «макдональдизації». Туристи все частіше відкидають промислову «фрордистську» модель масового виробництва недорогих продуктів, шука- 
ючи місцеву, свіжу і якісну кухню, яка відображає дійсність місця призначення. Згортання культури харчування на зразок «макдональдизації» призвело, наприклад, до того, що Starbucks зазнав невдачі в Австралії, оскільки бренд сприймається як позбавлений індивідуальності;

- зростання мультикультурного споживача. Мультикультуралізм став повсякденною концепцією в житті споживача, зумовленою імміграцією, глобалізацією, інтернетом, розширенням спеціалізованих телевізійних каналів і неухильним зростанням міжнародного туризму. Те, що колись було екзотичною їжею, стало бажаною їжею (наприклад, сьогодні каррі - улюблена страва Великобританії).

Гастрономічний туризм - це відмінний спосіб урізноманітнити вже застарілі види подорожей і залучити туристів в уже знайомі їм країни. Даний вид туризму зменшує негативний вплив сезонності, — в яку б пору року турист не відвідував країну, його завжди зустрінуть і смачно нагодують. У таких подорожах гість дізнається історію і культуру відвідуваної країни шляхом споживання кулінарних страв, водночас інформації, цікавої туристу, надходить набагато більше, ніж від звичайного відпочинку. Під час туру люди не тільки задовольняють свої біологічні потреби, а й ознайомлюються зі знавцями кулінарної справи, наприклад, з сім'ями, які з покоління в покоління займаються виноробством або готують сир. У тур також входить проживання, харчування та екскурсії найкрасивішими і незвичайними місцями регіону. Тривалість варіюється від трьох до чотирнадцяти днів. Цінова політика гастрономічної подорожі залежить від обраної країни, пори року та наявності екскурсійних об'єктів у програмі. Також варто зазначити, що у такого відпочинку відсутне поняття «гарячі тури». Гастрономічним туристом можна назвати людину, яка купує місцеву їжу і напої в країні тимчасового перебування і віддає перевагу високій кухні, а не кухні громадського харчування. До цієї категорії належать шефр-кухарі, сомельє, ресторанні критики, сім'ї з дітьми, корпоративні клієнти, працівники туристичних компаній, які віддають перевагу гастротурам для того, щоб здобути досвід і відкрити для себе нові смаки й аромати. Такі туристи дуже активні і допитливі, вони хочуть «спробувати на смак» якомога більше країн, через страви пізнати їх історію та культуру.

Важливо зазначити, що гастрономічний туризм - це щось більше, ніж послуга або подорож - це добре продуманий комплекс заходів для дегустації традиційних у конкретній дестинації страв, які не зустрічаються більше в жодній місцевості в світі, які так само мають ексклюзивний смак. Гастрономічний туризм має певні особливості, наприклад, розробка турів, процес дегустації страв, обробка продуктів для отримання цільної страви, яка не залишить байдужим жодного гостя (Leser, 1997). До того ж для реалізації проєктів гастрономічного туризму і просування турпродуктів на цільові ринки туризму необхідна організаційно-технологічна взаємодія суб'єктів туристичного ринку, органів влади та інших стейкхолдерів проєкту в межах єдиної концепції для забезпечення координації дій та досягнення поставлених цілей. До стейкхолдерів належать канали продажів гастрономічного туристичного продукту, туроператори, ресторатори, виноробні господарства, аграрні підприємства та екофрірми, асоціації підприємств сфрери туризму, органи влади, постачальники продукції і послуг, 
майданчики для проведення подій, event-агенції, що створюють гастрономічні події. Для кожного із них характерні свої цілі і завдання, пов'язані з отриманням прибутку, завоюванням частки ринку, просуванням турпродукту або бренду, залученням нових клієнтів і партнерів. 3 погляду регіонального турпродукту гастрономічний туризм цікавий мультиплікативним ефектом для різних суміжних галузей, зацікавлених у розвитку гастрономічного туризму і реалізації своєї продукції, а тому готові підключатися до його реалізації на різних етапах, а також брати участь у витратах на його просування в межах державно-приватного партнерства. Розвиток гастрономічного туризму сприяє зростанню впізнаваності місцевих харчових і продуктових брендів та їх просуванню на внутрішньому ринку. Це важлива складова так званого брендингу території - стратегії підвищення конкурентоспроможності дестинацій з метою заняття місць на ринку, залучення інвесторів, туристів, нових мешканців і висококваліфікованих мігрантів (Нехаева \& Терехова, 2015). Країни, які розвивають гастрономічний туризм, прагнуть до унікальності і намагаються показати бренд своєї території з позитивного боку, маючи на меті комерційні та політичні цілі у вигляді фрормування регіональної ідентичності ринку (Железова, 2013). Для України з її величезним національним, природним і культурним розмаїттям створення гастрономічних брендів може стати одним із вирішальних чинників заняття високих місць на зовнішніх ринках, залучення інвесторів, туристів, нових мешканців і висококваліфікованих мігрантів, а також збільшити джерела доходів у сільській місцевості та підвищити рівень доходів і зайнятості місцевого населення. Тому закономірно 2018 рік був названий роком гастротуризму в Україні, враховуючи думку рестораторів та експертів про нього як один із найперспективніших видів туризму в Україні, з яким країна може бути представлена в світі. На державному рівні активно розробляють національну концепцію гастрономічного туризму, що стане частиною загальнодержавної Стратегії розвитку туризму та курортів на період до 2026 року. Крім того, в країні відбувається чимало тематичних заходів.

\section{- Висновки}

Гастрономічний туризм є доволі молодим напрямом, який активно розвивається, але вже сьогодні чимало людей віддають перевагу не відпочинку на пляжі, а пізнанню традицій і звичаїв іншої країни шляхом дегустації національних страв і напоїв. Гастрономія дає змогу туристам отримувати доступ до культурної та історичної спадщини місця призначення через пізнання гастрономії, експериментування і купівлю продуктів. Гастрономічна традиція - процес, що постійно розвивається, і завдання для професіоналів полягає в тому, щоб залучити інновації, оновлювати й адаптувати свої пропозиції до потреб нової споживчої культури. Отже, гастрономічний туризм є стійким трендом, який уможливлює взаємодію мандрівників із місцевими громадами та дає змогу отримувати в поїздках нові враження. В умовах зростання конкуренції за увагу користувача і появи нових технологій бізнес-суб'єктам необхідно оперативно формувати оновлені стратегії просування. Практично будь-яка країна має потенціал для розвитку власного гастрономічного туризму, адже в кожній країні $€$ своя неповторна кух- 
ня. Гастрономічний туризм може стати одним із бажаних видів туризму, оскільки для того, щоб краще пізнати національну культуру регіону, необхідно випробувати його національну кухню.

Україна, безперечно, має потенціал підвищення міжнародної конкурентоспроможності туристичної галузі, зокрема завдяки посиленню мультикультуралізму туристичних потоків (залучення в них все більшої кількості жителів країн, що розвиваються), зростання попиту на нові туристичні дестинації, екотуризм, різноманітність культурного і природного ландшафту.

Водночас звертає на себе увагу потреба з'ясування чітких векторів розвитку гастрономічного туризму в країні, залучення кращого світового досвіду, розробки відповідної державної підтримки туристичних дестинацій, туристичних фрірм та інших стейкхолдерів, а також дослідження соціокультурних якостей туризму в контексті соціальних міграцій і діалектичної взаємодії загальносвітових процесів глобалізації та регіоналізації.

\section{- Список використаних джерел}

Глушко, В. (2016). Гастрономічний туризм як окремий вид у туризмі: поняття, сутність, класифрікація. Торгівля і ринок України, 39/40, 166-175.

Горова, Д. (2020, 5 листопада). Гастрономічний туризм в Україні та світі: чим цікавий та як все влаштовано. https://lowcost.ua/what-is-food-tourism/

Егорова, Е.А., \& Лях, О.А. (2016). Гастрономический туризм как перспективное направление развития туризма. В О.А. Лях (Ред.), Проблемы, опыт и перспективы развития туризма, сервиса и социокультурной деятельности в России и за рубежом, Материалы III Международной научно-практической интернет-конференции (с. 188-193). Забайкальский государственный университет.

Железова, О. Р. (2013). Этнический гастрономический туризм, его роль в сохранении национальной культуры и самобытности народов. Молодой ученый, 5(52), 855858.

Ковешніков, В. С., \& Гармаш, В. В. (2017). Винний та гастрономічний туризм: важливий потенціал розвитку економіки. Інвестиції: практика та досвід, 4, 32-37.

Коркуна, О. І., Никига, О. В., \& Підвальна, О. Г. (2020). Гастрономічний туризм як чинник соціально-економічного розвитку територіальних громад. Економічний простір, 155, 40-43.

Корнілова, В. В., \& Корнілова, Н. В. (2018). Сучасні тенденції розвитку гастрономічного туризму. Ефективна економіка, 2. http://www.economy.nayka.com.ua/ pdf/2_2018/37.pdf

Кукліна, Т. С. (2013). Гастрономічний туризм на туристичному ринку України. Научные труды SWorld, 44(1), 65-69.

Линькова, А. А., \& Максименко, А. Г. (2014). Актуальность включения гастрономических туров в программу туристских путешествий. Курортно-рекреационный комплекс в системе регионального развития: инновационные подходы, 1, 187-190.

Нестерчук, І. (2017). Гастрономічний туризм: історія, теорія і сучасні практики. Науковий вісник Херсонського державного університету. Серія: Географрічні науки, 6, 193-199. 
Нехаева, Н. Е., \& Терехова, Ю. С. (2015). Гастрономический туризм как перспективное направление развития регионов России. Естественные и математические науки в современном мире, 9(33), 82-87.

Саркісян, Г. О. (2020). Роль і значення стимулювання гастрономічного туризму в структурі розвитку регіональних туристичних ринків України. Український журнал прикладної економіки, 5(1), 312-320.

American Express. (2018, November 15). Travel Unveils Its Top Trending Travel Destinations for 2019. https://cutt.ly/ebUfGLV

Chan, W. Y., To, Ch. K., \& Chu, W. Ch. (2016). Desire for experiential travel, avoidance of rituality and social esteem: An empirical study of consumer response to tourism innovation. Journal of Innovation and Knowledge, 1(1), 24-35.

Leser, H. (1997). Diercke Wörterbuch Allgemeine Geographie. Deutscher Taschenbuch Verlag.

Ranteallo, I. C., \& Andilolo, I. R. (2017). Food Representation and Media: Experiencing Culinary Tourism Through Foodgasm and Foodporn. In Balancing Development and Sustainability in Tourism Destinations (pp. 117-127). Springer, Singapore.

Skift Megatrends. (n.d.). Travel Megatrends 2019. Retrieved April 20, 2021, from https://skift. com/megatrends-2019

Travel and Tourism Research Association. (2019, January 11). Top 5 Travel Trends for 2019. https://ttra.com/top-5-travel-trends-for-2019/

World Food Travel Association. (n.d.). State of the Food Industry Report. Retrieved April 20, 2021, from https://worldfoodtravel.org/annual-food-travel-industry-report

\section{- References}

American Express. (2018, November 15). Travel Unveils Its Top Trending Travel Destinations for 2019. https://cutt.ly/ebUfGLV [in English].

Chan, W. Y., To, Ch. K., \& Chu, W. Ch. (2016). Desire for experiential travel, avoidance of rituality and social esteem: An empirical study of consumer response to tourism innovation. Journal of Innovation and Knowledge, 1(1), 24-35 [in English].

Egorova, E. A., \& Lyakh, O.A. (2016). Gastronomicheskiy turizm kak perspektivnoe napravlenie razvitiya turizma [Gastronomic tourism as a promising area of tourism development]. In O. A. Lyakh (Ed.), Problemy, opyt i perspektivy razvitiya turizma, servisa i sotsiokul'turnoy deyatel'nosti v Rossii i za rubezhom [Problems, experience and prospects for the development of tourism, service and sociocultural activities in Russia and abroad], Proceedings of the III International Scientific and Practical Internet-Conference (pp. 188-193). Transbaikal State University [in Russian].

Hlushko, V. (2016). Hastronomichnyi turyzm yak okremyi vyd u turyzmi: poniattia, sutnist, klasyfikatsiia [Gastronomic tourism as a separate type in tourism: concept, essence, classification]. Trade and Market of Ukraine, 39/40, 166-175 [in Ukrainian].

Horova, D. (2020, November 5). Hastronomichnyi turyzm v Ukraini ta sviti: chym tsikavyi ta yak vse vlashtovano [Gastronomic tourism in Ukraine and the world: what is interesting and how everything is arranged]. https://lowcost.ua/what-is-food-tourism/ [in Ukrainian].

Korkuna, O. I., Nykyha, O. V., \& Pidvalna, O. H. (2020). Hastronomichnyi turyzm yak chynnyk sotsialno-ekonomichnoho rozvytku terytorialnykh hromad [Gastronomic tourism as 
a factor of socio-economic development of territorial communities]. Economic scope, 155, 40-43 [in Ukrainian].

Kornilova, V. V., \& Kornilova, N. V. (2018). Suchasni tendentsii rozvytku hastronomichnoho turyzmu [The Modern Trends of Gastronomic Tourism Development]. Efektyvna ekonomika, 2. http://www.economy.nayka.com.ua/pdf/2_2018/37.pdf [in Ukrainian].

Koveshnikov, V. S., \& Harmash, V. V. (2017). Vynnyi ta hastronomichnyi turyzm: vazhlyvyi potentsial rozvytku ekonomiky [Wine and gastronomic tourism: an important potential for economic development]. Investytsiyi: praktyka ta dosvid, 4, 32-37 [in Ukrainian].

Kuklina, T. S. (2013). Hastronomichnyi turyzm na turystychnomu rynku Ukrainy [Gastronomical Tourism on Ukrainian Tourism Market]. Nauchnye trudy SWorld, 44(1), 65-69 [in Ukrainian].

Leser, H. (1997). Diercke Wörterbuch Allgemeine Geographie [Diercke Dictionary General Geography]. Deutscher Taschenbuch Verlag [in German].

Lin'kova, A. A., \& Maksimenko, A. G. (2014). Aktual'nost' vklyucheniya gastronomicheskikh turov $\mathrm{v}$ programmu turistskikh puteshestvii [The relevance of the inclusion of gastronomic tours in the tourist travel program]. Kurortno-rekreatsionnyi kompleks $v$ sisteme regional'nogo razvitiya: innovatsionnye podkhody, 1, 187-190 [in Russian].

Nekhaeva, N. E., \& Terekhova, Yu. S. (2015). Gastronomicheskiy turizm kak perspektivnoe napravlenie razvitiya regionov Rossii [Gastronomic tourism as a promising direction for the development of Russian regions]. Estestvennye $i$ matematicheskie nauki $v$ sovremennom mire, 9(33), 82-87 [in Russian].

Nesterchuk, I. (2017). Hastronomichnyi turyzm: istoriia, teoriia i suchasni praktyky [Gastronomic tourism: history, theory and modern practices]. Scientific Bulletin of Kherson State University. Series Geographical Sciences, 6, 193-199 [in Ukrainian].

Ranteallo, I. C., \& Andilolo, I. R. (2017). Food Representation and Media: Experiencing Culinary Tourism Through Foodgasm and Foodporn. In Balancing Development and Sustainability in Tourism Destinations (pp. 117-127). Springer, Singapore [in English].

Sarkisian, H. O. (2020). Rol i znachennia stymuliuvannia hastronomichnoho turyzmu v strukturi rozvytku rehionalnykh turystychnykh rynkiv Ukrainy [The role and importance of stimulating gastronomic tourism in the structure of development of regional tourist markets of Ukraine]. Ukrainian Journal of Applied Economics, 5(1), 312-320 [in Ukrainian].

Skift Megatrends. (n.d.). Travel Megatrends 2019. Retrieved April 20, 2021, from https://skift. com/megatrends-2019 [in English].

Travel and Tourism Research Association. (2019, January 11). Top 5 Travel Trends for 2019. https://ttra.com/top-5-travel-trends-for-2019/ [in English].

World Food Travel Association. (n.d.). State of the Food Industry Report. Retrieved April 20, 2021, from https://worldfoodtravel.org/annual-food-travel-industry-report [in English].

Zhelezova, O. R. (2013). Etnicheskiy gastronomicheskiy turizm, ego rol' v sokhranenii natsional'noy kul'tury i samobytnosti narodov [Ethnic gastronomic tourism, its role in preserving the national culture and identity of peoples]. Young scientist, 5(52), 855-858 [in Russian]. 


\section{- FOOD TOURISM AS A CURRENT TREND IN MODERN CULTURE}

\section{Serhii Krasovskyi}

PhD in Cultural Studies, ORCID: 0000-0001-9314-7594, e-mail: krasovskiis89@gmail.com, Kyiv National University of Culture and Arts, Kyiv, Ukraine

\section{Abstract}

The purpose of the article is to analyse the formation and development of food tourism in the context of the sociocultural vector of understanding tourism concepts. The research methodology is based on applying a system-structural approach focused on the study of tourism as a holistic sociocultural phenomenon. The scientific novelty is that for the first time, the essence of food tourism is considered in the sociocultural aspect, which gives grounds to define it as a significant reagent for influencing social processes. Conclusions. It is emphasised that food tourism is a reasonably young direction, which is actively developing. Still, even today, many people prefer to learn about the traditions and customs of another country through tasting ethnic dishes and drinks. Therefore, given that the gastronomic tradition is an ever-evolving process, the challenge for professionals is to incorporate innovation, update and adapt their offerings to the needs of the new consumer culture. World development trends of food tourism suggest a sustainable movement that allows travellers to interact with local communities and gain fresh experiences on travel. Businesses need to develop updated promotion strategies under competitive expansion for the users' attention and the emergence of new technologies. Ukraine undoubtedly has the potential to increase the international competitiveness of the tourism industry, including through increased multiculturalism of tourist flows (including more and more people from developing countries), growing demand for new tourist destinations, ecotourism, diversity of cultural and natural landscape. The article draws attention to the need to clarify precise vectors of gastronomic tourism in the country, attract the best world experience, develop appropriate state support for tourist destinations, travel agencies and other stakeholders, as well as study the sociocultural qualities of tourism in the context of social migration and dialectical interaction of global processes regionalisation.

Keywords: tourism; food tourism; destination; ethnic culture; travel services market 


\section{ГАСТРОНОМИЧЕСКИЙ ТУРИЗМ КАК АКТУАЛЬНЫЙ ТРЕНД СОВРЕМЕННОЙ КУЛЬТУРЫ}

\section{- Красовский Сергей Александрович}

Кандидат культурологии,

ORCID: 0000-0001-9314-7594, e-mail: krasovskiis89@gmail.com,

Киевский национальный университет культуры и искусств,

Киев, Украина

\section{Аннотация}

Цель статьи - проанализировать формирование и развитие гастрономического туризма в контексте социокультурного вектора понимания сущности туристической деятельности. Методология исследования основана на применении системноструктурного подхода, ориентированного на изучение туризма как целостного социокультурного явления. Научная новизна заключается в том, что впервые сущность гастрономического туризма рассмотрена в социокультурном аспекте, что позволяет определить его как значимый реагент влияния на социальные процессы. Выводы. Гастрономический туризм довольно молодое, активно развивающееся направление, но уже сегодня многие предпочитают познание традиций и обычаев другой страны благодаря дегустации национальных блюд и напитков. Поэтому, учитывая, что гастрономическая традиция - это постоянно развивающийся процесс, задача для профессионалов заключается в том, чтобы включить инновации, обновлять и адаптировать свои предложения к потребностям новой потребительской культуры. Тенденции развития гастрономического туризма в мире дают основания считать его устойчивым трендом, который делает возможным взаимодействие путешественников с местными общинами и получение в поездках новых впечатлений. В условиях роста конкуренции за внимание пользователя и появления новых технологий бизнес-субъектам необходимо оперативно формировать обновленные стратегии продвижения. Определено, что Украина имеет потенциал для повышения международной конкурентоспособности туристической отрасли, в частности благодаря усилению мультикультурализма туристических потоков, росту спроса на новые туристические дестинации, разнообразию культурного и природного ландшафта. Обращено внимание на необходимость выяснения четких векторов развития гастрономического туризма в стране, разработки соответствующей государственной поддержки туристических дестинаций, туристических фрирм и других стейкхолдеров, а также исследования социокультурных качеств туризма в контексте социальных миграций и диалектического взаимодействия общемировых процессов глобализации и регионализации.

Ключевые слова: туризм; гастрономический туризм; дестинация; национальная культура; рынок туристических услуг 